\title{
Decomposition and nutrient release patterns of the leaf biomass of the wild sunflower (Tithonia diversifolia): a comparative study with four leguminous agroforestry species
}

\author{
S. T. Partey · S. J. Quashie-Sam • \\ N. V. Thevathasan · A. M. Gordon
}

Received: 8 July 2009/Accepted: 19 November 2010/Published online: 3 December 2010

(C) Springer Science+Business Media B.V. 2010

\begin{abstract}
The selection and use of appropriate plant materials to maintain a sufficiently high nutrient supply to meet crop needs remains a major challenge of nutrient management under low input systems. Therefore, research on plant biomass quality as it relates to decomposition and nutrient release has become imperative. This research was conducted at the Agroforestry Research Station of the Kwame Nkrumah University of Science and Technology, Kumasi, Ghana to determine the decomposition and nutrient release patterns of Tithonia diversifolia, a rarely used non-traditional species but of research interest in soil fertility improvement practices in Ghana. The decomposition and nutrient release patterns of $T$. diversifolia was compared with Senna spectabilis, Gliricidia sepium, Leucaena leucocephala and Acacia auriculiformis which are commonly used in biomass transfer systems.
\end{abstract}

S. T. Partey · S. J. Quashie-Sam

Faculty of Renewable Natural Resources, Kwame

Nkrumah University of Science and Technology,

Kumasi, Ghana

N. V. Thevathasan · A. M. Gordon

School of Environmental Sciences, University of Guelph,

N1G 2W1 Guelph, Ontario, Canada

Present Address:

S. T. Partey $(\square)$

Faculty of Life Sciences, University of Manchester,

Michael Smith Building, Oxford Road,

Manchester M13 9PL, UK

e-mail: sammtech147@yahoo.co.uk
Results of the study confirmed significantly high N, P, $\mathrm{K}$ concentrations in $T$. diversifolia comparable to levels recorded for the four leguminous species. In addition, $T$. diversifolia recorded the highest percent decomposition and nutrient release rates which differed significantly $(P<0.05)$ from rates of the four leguminous species. It was apparent from the study that decomposition and nutrient release rates of species are related to quality of leaf material. Phosphorus and $\mathrm{Mg}$ concentration in particular were most influential in decomposition and nutrient release based on significant results. For this reason, it would be imperative to consider the concentrations of $\mathrm{P}$ and $\mathrm{Mg}$ among other factors in selecting high quality plant materials for green manuring.

Keywords Biomass quality $\cdot$ Nutrient concentrations $\cdot T$. diversifolia $\cdot$ Decomposition

\section{Introduction}

In Africa, land productivity and food production have for several decades depended on a system of shifting cultivation characterized by a long period of fallow with a relatively short cropping period (Nye and Stephens 1962). This traditional practice of shifting cultivation and related bush fallow systems have for generations provided resource-poor farmers with an efficient and stable food production system with no purchased inputs (Sanchez and Salinas 1981). Nair 
(1984) attributed the effectiveness of this system to the constant cycle and transfer of nutrients from one compartment of the system to another, which operates through the physical and biological processes of canopy wash, litter-fall, root decomposition and plant uptake. Although shifting cultivation with long fallow periods was an accepted soil fertility improvement system (Nair 1984), the increased population pressure on cropping land, and the concomitant shortening of fallow periods, limits soil fertility regeneration under this system (Getahun and Wilson 1982). Although fertilizers have been beneficial in improving soil fertility at places where shifting cultivation has been limited, it is increasingly difficult for smallholder farmers who earn less than one dollar a day to afford the fertilizer requirements in many developing countries. This makes alternative means of improving soil fertility highly imperative.

According to George et al. (2001), the incorporation of woody perennials into cropping systems via agroforestry can help sustain agricultural production. This is because, the addition of plant residues from the tree component to the soil plays a critical role by contributing to recycling of plant nutrients, improvements in soil structure, microbial activities and maintenance of high soil nutrient status (Wu et al. 2000; Vanlauwe et al. 2001). Although biomass transfer systems involving leguminous species such as Leucaena leucocephala, Gliricidia sepium, Senna spectabilis and Acacia auriculiformis have made substantial contributions to the development of low input soil fertility improvement practices in the tropics, the selection and use of appropriate plant materials to maintain a sufficiently high nutrient supply to meet crop needs, still remains a major challenge of nutrient management under these low input systems (Kwabiah et al. 2001). Since the extent to which plant residues influences soil fertility and crop growth is in part determined by their biochemical qualities, decomposition and the concurrent timing of nutrient release and crop nutrient demand (Koenig and Cochran 1994), understanding the decomposition and nutrient release patterns of plant biomass will be crucial in manipulating their incorporation into cropping systems to improve nutrient synchronization.

Recently, the potential of the green biomass of the Mexican sunflower (Tithonia diversifolia) for soil fertility improvement and crop production has gained tremendous research interest in many parts of Africa (Niang et al. 1996; Gachengo et al. 1999). A member of the asteraceae family, T. diversifolia is briefly a succulent and soft shrub plant that grows to a height of 1-3 $\mathrm{m}$; and bears alternately positioned leaves along most of the stem (ICRAF 1997). It originates from Mexico and its now wildly distributed in Africa, Asia and South America (Jama et al. 2000). In Kenya and many parts of Africa, foliar analysis of T. diversifolia green biomass revealed relatively high nutrient $(\mathrm{N}, \mathrm{P}, \mathrm{K}, \mathrm{Ca}$ and $\mathrm{Mg}$ ) concentrations comparable to most leguminous species used in biomass transfers (Jama et al. 2000). Although the mechanisms by which $T$. diversifolia acquires and accumulates nutrients in its leaf tissues are largely unknown, several researchers have confirmed that T. diversifolia biomass used as green manure rapidly releases accumulated nutrients into the soil, making them available to crops (George et al. 2001; Jama et al. 2000; Cobo et al. 2002). In addition, field experiment conducted on a chromic acrisol in Morogoro, Tanzania, showed that the application of T. diversifolia green manure enhances $\mathrm{P}$ availability and improves maize yields through modification of soil properties, such as soil $\mathrm{pH}$, exchangeable $\mathrm{Al}$ and exchangeable $\mathrm{Ca}$, which are associated with $\mathrm{P}$ transformation and availability (Ikerra et al. 2006). Although research confirms $T$. diversifolia leaf nutrient concentrations and its implications on biomass transfers (George et al. 2001), less is reported on the decomposition and nutrient release patterns of $T$. diversifolia leaf biomass. Using the chemical characteristics of $T$. diversifolia leaf biomass and its decomposition and nutrient release patterns (Swift et al. 1979), we conducted a field research to evaluate the suitability of $T$. diversifolia green biomass for soil fertility improvement in Ghana. This was conducted in comparison with S. spectabilis, L. leucocephala, A. auriculiformis and G. sepium which are commonly used in biomass transfer systems in Ghana.

\section{Materials and methods}

Study site

The study was conducted at the Agroforestry Research Station of the Faculty of Renewable Natural Resources (FRNR), Kwame Nkrumah University of 
Science and Technology (KNUST), Kumasi, Ghana, located at Lat $0143^{\circ} \mathrm{N}$ and Long $0136^{\circ} \mathrm{W}$. The research area had lied fallow for $1 \frac{1}{2}$ years after 2 years of maize cultivation with no external inputs. The area falls within the moist semi-deciduous forest zone of Ghana and it is characterized by a bimodal rainfall pattern, with the major wet season between May and July. This area also experiences a short dry season in August and a long one between December and March. The annual rainfall of the area ranges between 1,250 and $1,500 \mathrm{~mm}$. The area is characterized by a mean annual temperature of $26.6^{\circ} \mathrm{C}$ and a mean annual humidity of $67.6 \%$. Climatic data collected during the research period is shown in Fig. 1. Soil type at study site is a ferric acrisol with extreme acidic condition according to the soil reaction rating by Motsara and Roy (2008). In addition, the soil has moderate levels of $\mathrm{N}$ and organic matter (Table 1).

Experimental design and sampling procedure

Plant species used in the study were: $T$. diversifolia, G. sepium, L. leucocephala, S. spectabilis and A. auriculiformis. The selection of these species was based on their relative abundance at the study area and their use as organic amendments for soil fertility improvement. Fresh leaves of these species including petioles (in the case of $T$. diversifolia, G. sepium and A. auriculiformis) and rachis in the case of L. leucocephala and S. spectabilis (since they have compound leaves) were collected from already established fields at study site and characterized for quality parameters. Samples of fresh leaves collected

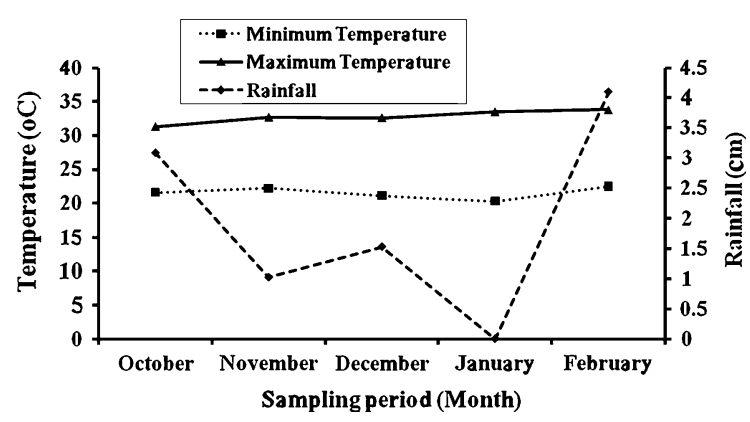

Fig. 1 Mean monthly rainfall and temperature recordings during the experimental period at the agroforestry research station. Minimum and maximum temperatures represent monthly means
Table 1 Physico-chemical properties of the top-soil $(0-15 \mathrm{~cm})$ of the experimental site at the Agroforestry Research Station, Kumasi, Ghana

\begin{tabular}{ll}
\hline Parameter & Value \\
\hline $\mathrm{pH}\left(\mathrm{H}_{2} 0\right)(1: 1)$ & 4.05 \\
Organic C $(\mathrm{g} / \mathrm{kg})$ & 22.9 \\
Organic matter $(\mathrm{g} / \mathrm{kg})$ & 39.5 \\
Total N $(\mathrm{g} / \mathrm{kg})$ & 2.2 \\
Available Bray-1 P $(\mathrm{mg} / \mathrm{kg})$ & 5.64 \\
Available Bray-1 K $(\mathrm{mg} / \mathrm{kg})$ & 251 \\
Exchangeable cations $(\mathrm{cmol} / \mathrm{cg})$ & \\
Ca & 3.7 \\
Mg & 2.4 \\
$\mathrm{~K}$ & 0.4 \\
Na & 0.1 \\
Exchangeable acidity $(\mathrm{Al}+\mathrm{H})(\mathrm{cmol} / \mathrm{kg})$ & 0.6 \\
ECEC $(\mathrm{cmol} / \mathrm{kg})$ & 7.1 \\
Base saturation $(\%)$ & 92 \\
Texture $(\mathrm{g} / \mathrm{kg})$ & \\
Sand & 604 \\
Silt & 355 \\
Clay & 41 \\
\hline
\end{tabular}

were air-dried and ground to pass through a $0.5 \mathrm{~mm}$ sieve and analyzed for total $\mathrm{N}, \mathrm{P}, \mathrm{K}, \mathrm{Ca}, \mathrm{Mg}$ and organic C. Nitrogen was determined by the Kjeldahl method, potassium was determined in an ash solution using a Gallenkamp flame analyzer, phosphorus by the ammonium phosphomolybdate method (Motsara and Roy 2008), carbon by the gravimetric ash method and calcium and magnesium by the EDTA titration method (Motsara and Roy 2008).

The decomposition and nutrient release patterns of the selected species were studied using the littler-bag technique. Fresh leaves of T. diversifolia, G. sepium, L. leucocephala, S. spectabilis and A. auriculiformis equivalent to $40 \mathrm{~g}$ on a dry weight basis were collected from the agroforestry research station and placed in a $22 \times 50 \mathrm{~cm}$ rigid nylon litter-bag of $1.5 \mathrm{~mm}$ mesh size. The litter-bags were placed within plough depth $(0-15 \mathrm{~cm})$ with $0.5 \mathrm{~m}$ spacing between them. Using plant species as treatments, litter bags were arranged in a randomized complete block design with five replications. At 1, 2, 4, 8 and 12 weeks of decomposition, five litter-bags (representing five replicates) for each species were randomly selected to follow dry matter and nutrient 
losses. Plant materials remaining in the litter-bags at each sampling time were separated from soil and organic debris by hand and oven dried at $65^{\circ} \mathrm{C}$ to constant weight. The oven-dried samples were separately weighed to determine dry matter losses and thereafter grounded to pass a $0.5 \mathrm{~mm}$ sieve for biochemical analysis. The biochemical analysis was done separately for each replicate. In order to correct for contamination by the mineral soil, samples were ashed at $450^{\circ} \mathrm{C}$ for $4 \mathrm{~h}$. The difference between the dry weight of the decomposed leaves and their ash contents were taken as the ash-free dry weight. The amount of nutrients remaining in the litterbags at each sampling time was determined by multiplying the ash-free dry weight of the mass of leaves remaining by their nutrient concentrations. The percent dry weight and nutrient remaining (on ashfree basis) at each sampling time was calculated using the relation:

$A_{R}=\frac{A t}{A o} \times 100 \%$

Where $A_{R}$ is the percent nutrient or quantity of plant material remaining, At is the amount of plant material or nutrient remaining at each sampling time and $A o$ is the initial weight of plant material or nutrient concentration.

\section{Statistical analysis}

Data collected on the dry weight and nutrient remaining (on ash-free basis) in decomposing leaves at each sampling time were analyzed using analysis of variance (ANOVA). Least significant difference at $P \leq 0.05$ was used to make treatment comparisons. Percent dry weight and nutrient remaining (on ashfree basis) were regressed on time using nonlinear regression models. Nonlinear regression models were produced using standard curve procedures in GENSTAT 11 (VSN International Ltd 2008). The single three parameter exponential model (Wieder and Lang 1982) was used to determine the decomposition and nutrient release rate constant $(k)$. Root mean square error values were used to assess fit of the models. The best fit model was determined based on lowest root mean square error values. The general form of the model was:
$Y=\beta_{o}+\beta_{i} e^{-k t}+$ error

Where $Y$ is the percent of initial material or nutrient remaining at sampling time $t, \beta_{o}$ is the recalcitrant pool fraction and $\beta_{i}$ is the difference $100-\beta_{o}$. Correlation and regression analysis were also carried out between chemical parameters of the plant materials used in the litterbags and their decomposition and nutrient release rates.

\section{Results}

Quality of plant materials

With the exception of C, ANOVA test on the initial foliar analysis showed significant differences $(P<0.05)$ in $\mathrm{N}, \mathrm{P}, \mathrm{K}, \mathrm{Ca}$ and $\mathrm{Mg}$ concentrations measured for the different leaf materials. All plant materials had $\mathrm{C}$ : $\mathrm{N}$ ratios narrower than 32:1 beyond which soil $\mathrm{N}$ immobilization can be expected (Troeh and Thompson 2005). Carbon to nitrogen ratios varied from 16 in $T$. diversifolia to 22 in A. auriculiformis. Among the different plant materials analyzed, $A$. auriculiformis and L. leucocephala recorded C: P ratios greater than 200:1 which represent threshold value for initial net mineralization of P (Schroth 2003). Nitrogen concentration in $T$. diversifolia was highest and significantly different from levels recorded for the other four species. However, recorded $\mathrm{N}$ concentrations for all tested species were above the critical level of 20-25 g/ $/ \mathrm{kg}$, below which net immobilization of $\mathrm{N}$ would be expected (Palm et al. 1997). Nitrogen levels ranged from $21.5 \mathrm{~g} / \mathrm{kg}$ in A. auriculiformis to $33.6 \mathrm{~g} / \mathrm{kg}$ in T. diversifolia. Phosphorus concentration in A. auriculiformis, and L. leucocephala were below the critical level of $25 \mathrm{~g} / \mathrm{kg}$, below which net P immobilization would occur (Palm et al. 1997). However, P levels in all species were high compared to levels in other tropical species (Vitousek 1984). Potassium level was highest in $G$. sepium and the same for $T$. diversifolia and L. leucocephala. Calcium and magnesium levels recorded for the five species, followed the increasing order of $S$. spectabilis $<G$. sepium $<L$. leucocephala $<T$. diversifolia $<$ A. auriculiformis and A. auriculiformis $<S . \quad$ spectabilis $<L . \quad$ leucocephala $<G$. sepium $<T$. diversifolia, respectively (Table 2 ). 
Table 2 Chemical characteristics of species used in decomposition experiment $\mathrm{g} / \mathrm{kg}$

\begin{tabular}{lrllrllll}
\hline Treatment & $\mathrm{N}$ & $\mathrm{P}$ & $\mathrm{K}$ & $\mathrm{Ca}$ & $\mathrm{Mg}$ & $\mathrm{C}$ & $\mathrm{C}: \mathrm{N}$ & $\mathrm{C}: \mathrm{P}$ \\
\hline$A a$ & 21.5 & 1.5 & 5.0 & 14.7 & 3.4 & 479.2 & 22.29 & 320.6 \\
$\mathrm{Ss}$ & 29.9 & 2.6 & 5.4 & 6.5 & 5.1 & 466.2 & 15.61 & 179.7 \\
$\mathrm{Ll}$ & 25.6 & 2.0 & 6.2 & 12.8 & 6.1 & 478.7 & 18.70 & 240.7 \\
$\mathrm{Td}$ & 33.6 & 4.2 & 6.2 & 13.6 & 9.2 & 457.3 & 13.61 & 108.9 \\
$G s$ & 28.7 & 3.0 & 6.4 & 8.0 & 6.7 & 471.0 & 16.41 & 157.4 \\
$\mathrm{LSD}_{0.05}$ & 0.6 & 0.2 & 0.5 & 0.6 & 0.2 & 20.0 & 0.9 & 19.9 \\
\hline
\end{tabular}

(Aa Acacia auriculiformis, Ss Senna spectabilis, Ll Leucaena leucocephala, Td Tithonia diversifolia, Gs Gliricidia sepium; $L S D$ least square difference

\section{Decomposition patterns}

The highest dry weight loss occurred in $T$. diversifolia during the first week of the experiment and lowest in A. auriculiformis (Fig. 2). Percent dry weight remaining after the first week of decomposition ranged from $20 \%$ in $T$. diversifolia to $82 \%$ in A. auriculiformis. During the same period, $49 \%$ of G. sepium leaves had decomposed which increased rapidly to $77 \%$ after the second week. After 8 weeks, the amount of $T$. diversifolia leaf material remaining was insignificant (and inseparable from mineral soil) compared with all species, especially with A. auriculiformis recording about $31 \%$ of decomposing leaf material remaining on the 12 th week of the experiment. With the exception of L. leucocephala which had a biphasic decomposition pattern, all plant

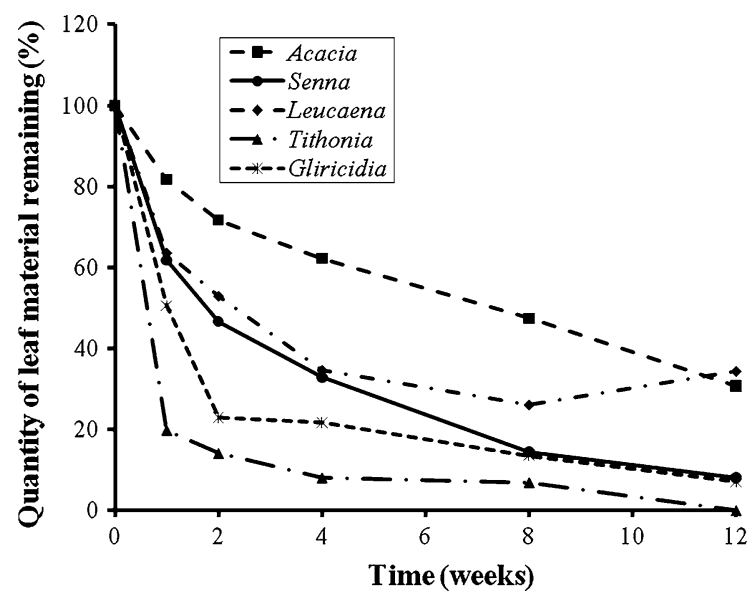

Fig. 2 Quantity of initial leaf material remaining from decomposing leaves over 12 weeks materials generally showed steady and uniform increase in decomposition through time.

Analysis of variance test confirmed significant $(P<0.05)$ effect of species type on decomposition rates at all sampling periods. As revealed by the statistical comparison, decomposition rates in both $S$. spectabilis and $L$. leucocephala were similar during the first 28 days of decomposition (Table 3). Generally, percent decomposition rate was highest in T. diversifolia and lowest in A. auriculiformis. With the exception of $A$. auriculiformis, decomposition rate decreased with increasing period of decomposition. The decomposition rate of $T$. diversifolia differed significantly $(P<0.05)$ from all species. In addition, statistics revealed a significant $(P<0.01)$ nonlinear relationship between percent decomposing rate and time (Table 4).

Nutrient release patterns

Data collected showed marked differences in $\mathrm{N}, \mathrm{P}$, $\mathrm{K}, \mathrm{Ca}$ and $\mathrm{Mg}$ release patterns in the decomposing leaf materials of A. auriculiformis, S. spectabilis, L. leucocephala, T. diversifolia and G. sepium. With the exception of $\mathrm{K}$ in L. leucocephala and $\mathrm{Mg}$ in $T$. diversifolia, nutrient release rates were generally higher than decomposition rates among species. The highest percent $\mathrm{N}, \mathrm{P}, \mathrm{K}, \mathrm{Ca}$ and $\mathrm{Mg}$ released was recorded for $T$. diversifolia during the first week and even afterwards. Between 4 and 8 weeks of decomposition, $\mathrm{N}$ immobilization apparently occurred in A. auriculiformis, $S$. spectabilis, L. leucocephala and G. sepium whilst $T$. diversifolia mineralized its leaf $\mathrm{N}$ at a relative faster rate. Nitrogen retention in decomposing leaves at the end of the study period were less than $32 \%$ and followed the increasing order of $T$. diversifolia (undeterminable level) $<S$. spectabilis $<G$. sepium $<A$. auriculiformis $<L$. leucocephala (Fig. 3). Even though $\mathrm{N}$ release pattern differed from patterns observed for decomposition, percent $\mathrm{N}$ release rate $\left(k_{\mathrm{N}}\right.$ day $\left.^{-1}\right)$ was also highest in $T$. diversifolia $\left(0.328 \mathrm{day}^{-1}\right)$ and lowest in A. auriculiformis $\left(0.056 \mathrm{day}^{-1}\right)$. Percent $\mathrm{N}$ release rate followed the increasing order of $A$. auriculiformis $<S$. $\quad$ spectabilis $<L$. leucocephala $<G$. sepium $<T$. diversifolia (Table 5). Correlation and regression analysis confirmed a significant positive correlation between $k_{\mathrm{N}}$ day $^{-1}$ and $\mathrm{P}(P<0.05, r=$ 0.93); and $\mathrm{Mg}$ concentrations $(P<0.01, r=0.96$; 
Table 3 Decomposition rates $\left(k_{\mathrm{D}}\right.$ day $\left.{ }^{-1}\right)$ of different leaf materials as influenced by species type under field conditions

\begin{tabular}{|c|c|c|c|c|c|}
\hline \multirow{2}{*}{$\begin{array}{l}\text { Decomposition } \\
\operatorname{rates}^{\mathrm{a}} / \text { species }\end{array}$} & \multicolumn{5}{|c|}{ Sampling period (days) } \\
\hline & 7 & 14 & 28 & 56 & 84 \\
\hline A. auriculiformis & 0.029 & 0.024 & 0.017 & 0.013 & 0.014 \\
\hline S. spectabilis & 0.069 & 0.055 & 0.040 & 0.035 & 0.030 \\
\hline L. leucocephala & 0.065 & 0.045 & 0.038 & 0.024 & 0.013 \\
\hline T. diversifolia & 0.231 & 0.136 & 0.088 & 0.048 & $0 *$ \\
\hline G. sepium & 0.097 & 0.109 & 0.055 & 0.036 & 0.032 \\
\hline $\mathrm{LSD}_{0.05}$ & 0.005 & 0.016 & 0.016 & 0.002 & 0.002 \\
\hline
\end{tabular}

* Zero because leaf materials remaining could not be quantified. Leaf material was inseparable from soil mineral particles

a Decomposition rates are in percentages

Table 4 Nonlinear regression models for weight loss of leaf material

\begin{tabular}{lllll}
\hline Species & Equation & $R^{2}$ & $S_{\mathrm{yx} \dagger}$ & $P$ value $\dagger$ \\
\hline Acacia auriculiformis & $Y=24.8+71.5 \mathrm{e}^{-0.025 \mathrm{t}}$ & 0.98 & 4.90 & 0.004 \\
Senna spectabilis & $Y=10.82+86.29 \mathrm{e}^{-0.061 \mathrm{t}}$ & 0.98 & 5.46 & 0.002 \\
Leucaena leucocephala & $Y=30.24+69.13 \mathrm{e}^{-0.092 \mathrm{t}}$ & 0.98 & 4.48 & 0.002 \\
Tithonia diversifolia & $Y=6.21+93.64 \mathrm{e}^{-0.258 \mathrm{t}}$ & 0.99 & 4.97 & 0.001 \\
Gliricidia sepium & $Y=12.16+88.0 \mathrm{e}^{-0.125 \mathrm{t}}$ & 0.98 & 5.74 & 0.002 \\
\hline
\end{tabular}

$\uparrow$ Standard error of estimate

+ Significance of fit

$R^{2}=$ coefficient of determination

Table 6). Analysis of variance test also confirmed significant $(P<0.05)$ effect of species type on $k_{\mathrm{N}}$ day $^{-1}$. Significant differences in $k_{\mathrm{N}}$ day $^{-1}$ among species was observed during the second, fourth and eighth weeks of decomposition. At weeks 1 and 12, there were no significant differences in $k_{\mathrm{N}}$ day ${ }^{-1}$ among the following pairs: $S$. spectabilis and $L$. leucocephala; and $A$. auriculiformis and $L$. leucocephala respectively. Meanwhile, $k_{\mathrm{N}} \mathrm{day}^{-1}$ in $T$. diversifolia differed significantly from all species (Table 7).

Phosphorus released increased steadily among species through time. However, $\mathrm{P}$ immobilization occurred in L. leucocephala between the 8th and 12th week of decomposition. As observed for N, phosphorus release rates $\left(k_{\mathrm{P}}\right.$ day $\left.^{-1}\right)$ were highest in T. diversifolia and lowest in A. auriculiformis. Phosphorus release rate had a significant positive correlation with $\mathrm{P}(P<0.05)$ and $\mathrm{Mg}(P<0.01)$ concentrations. In addition, ANOVA test confirmed significant $(P<0.05)$ effect of species type on $k_{\mathrm{P}}$ day $^{-1}$ with no significant differences $(P>0.05)$ in $k_{\mathrm{P}}$ day $^{-1}$ between $S$. spectabilis and Leucocephala at weeks 1,2 and 4 of decomposition. In addition, differences in $k_{\mathrm{P}}$ day $^{-1}$ at weeks 4 and 8 were not significant between $L$. leucocephala and G. sepium; and S. spectabilis and G. sepium respectively.

Potassium happened to be the element with the fastest release rate among species with its dynamic pattern differing among species. With the exception of weeks 2 and 4 , potassium release rate $\left(k_{\mathrm{K}}\right.$ day $\left.^{-1}\right)$ differed significantly among all species. At week 2 , $k_{\mathrm{K}}$ day $^{-1}$ did not differ significantly $(P>0.05)$ between $A$. auriculiformis and L. leucocephala. This observation also occurred at week 4 together with the following pairs: A. auriculiformis and S. spectabilis; S. spectabilis and L. leucocephala; L. leucocephala and T. diversifolia; L. leucocephala and G. sepium; and T. diversifolia and G. sepium. Potassium release rate followed the order: $T$. diversifolia $>G$. sepium $>$ S. spectabilis $>$ L. leucocephala $>$ A. auriculiformis.

Between 4 and 8 weeks of decomposition, $\mathrm{Mg}$ immobilization was recorded for A. auriculiformis, $L$. leucocephala, and $G$. sepium which were later mineralized at a relatively faster rate especially in $A$. auriculiformis. Calcium release rate $\left(k_{\mathrm{Ca}} \mathrm{day}^{-1}\right)$ was 
Fig. $3 \mathrm{~N}, \mathrm{P}, \mathrm{K}, \mathrm{Ca}$ and $\mathrm{Mg}$ release patterns in decomposing leaf materials of Tithonia diversifolia (Td), Acacia auriculiformis (Aa), Senna spectabilis $(\mathrm{Ss})$, Leucaena leucocephala $(\mathrm{Ll})$ and Gliricidia sepium (Gs) over 12 weeks of placement in soil
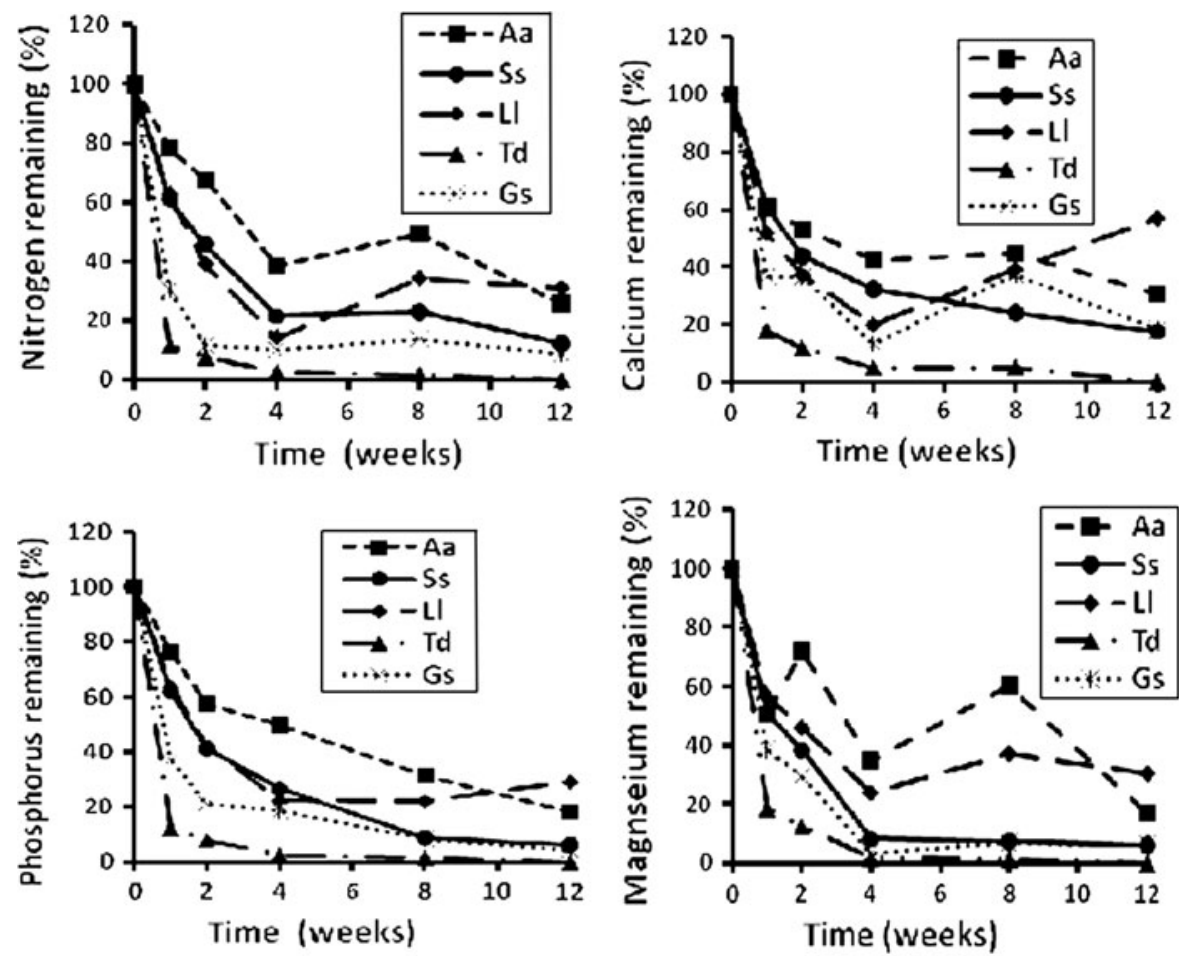

fastest in $T$. diversifolia and slowest in S. spectabilis during the first week of decomposition. Meanwhile, an increase in decomposition generally resulted in an increase in nutrient release rates with the exception of Ca.

\section{Discussions and conclusion}

As expected, differences in biochemical composition were apparent among the species. Although T. diversifolia is non-leguminous, its $\mathrm{N}$ concentration was comparable and significantly higher than levels recorded for the four leguminous species. The N, P and $\mathrm{K}$ levels of $T$. diversifolia recorded in this study were comparable to the observations of Jama et al. (2000) who confirmed high nutrient composition values of $T$. diversifolia green manure in comparison with six different agroforestry species used in soil fertility improvement practices (Table 8). Although the mechanism by which $T$. diversifolia is able to build nutrients in its biomass is unclear, it is evident to have a tremendous scavenging ability in pumping these nutrients from large volumes of soil and accumulating them in the leaves: an attribute of the Asteraceae family of $T$. diversifolia (Garrity and Mercado 1994). This scavenging characteristic of $T$. diversifolia might restrict its establishment in association with annual crops. In addition, $T$. diversifolia roots are confirmed to be associated with 
Table 5 Nonlinear regression models for nutrient loss in leaf materials

\begin{tabular}{|c|c|c|c|c|}
\hline Nutrient/species & Equation & $S_{\mathrm{yx}}$ & $R^{2}$ & $P$ value \\
\hline \multicolumn{5}{|l|}{ Nitrogen } \\
\hline Acacia auriculiformis & $Y=33.16+67.2 \mathrm{e}^{-0.056 \mathrm{t}}$ & 10.6 & 0.91 & 0.027 \\
\hline Senna spectabilis & $Y=16.43+83.14 \mathrm{e}^{-0.083 \mathrm{t}}$ & 5.0 & 0.99 & 0.002 \\
\hline Leucaena leucocephala & $Y=26.54+74.9 \mathrm{e}^{-0.124 \mathrm{t}}$ & 10.3 & 0.93 & 0.018 \\
\hline Tithonia diversifolia & $Y=2.51+97.45 \mathrm{e}^{-0.328 \mathrm{t}}$ & 2.87 & 1.0 & $<0.001$ \\
\hline Gliricidia sepium & $Y=10.21+89.90 \mathrm{e}^{-0.222 \mathrm{t}}$ & 2.79 & 1.0 & $<0.001$ \\
\hline \multicolumn{5}{|l|}{ Phosphorus } \\
\hline Acacia auriculiformis & $Y=19.96+77.22 \mathrm{e}^{-0.041 \mathrm{t}}$ & 5.97 & 0.98 & 0.004 \\
\hline Senna spectabilis & $Y=7.53+90.98 \mathrm{e}^{-0.067 \mathrm{t}}$ & 3.72 & 0.99 & $<0.001$ \\
\hline Leucaena leucocephala & $Y=23.68+77.21 \mathrm{e}^{-0.103 \mathrm{t}}$ & 4.85 & 0.98 & 0.002 \\
\hline Tithonia diversifolia & $Y=2.63+97.32 \mathrm{e}^{-0.317 \mathrm{t}}$ & 2.98 & 1.0 & $<0.001$ \\
\hline Gliricidia sepium & $Y=10.16+89.41 \mathrm{e}^{-0.160 t}$ & 5.88 & 0.98 & 0.002 \\
\hline \multicolumn{5}{|l|}{ Potassium } \\
\hline Acacia auriculiformis & $Y=6.56+90.71 \mathrm{e}^{-0.079 t}$ & 4.81 & 0.98 & 0.003 \\
\hline Senna spectabilis & $Y=0.84+99.73 \mathrm{e}^{-0.093 \mathrm{t}}$ & 1.75 & 1.0 & $<0.001$ \\
\hline Leucaena leucocephala & $Y=2.80+96.31 \mathrm{e}^{-0.089 t}$ & 7.11 & 0.98 & 0.003 \\
\hline Tithonia diversifolia & $Y=1.94+97.90 \mathrm{e}^{-0.261 \mathrm{t}}$ & 4.19 & 0.99 & $<0.001$ \\
\hline Gliricidia sepium & $Y=3.95+95.48 \mathrm{e}^{-0.141 \mathrm{t}}$ & 4.01 & 0.99 & $<0.001$ \\
\hline \multicolumn{5}{|l|}{ Calcium } \\
\hline Acacia auriculiformis & $Y=38.8+60.36 \mathrm{e}^{-0.123 \mathrm{t}}$ & 6.54 & 0.96 & 0.009 \\
\hline Senna spectabilis & $Y=21.77+77.21 \mathrm{e}^{-0.089 \mathrm{t}}$ & 3.93 & 0.99 & 0.001 \\
\hline Leucaena leucocephala & $Y=38.13+62.1 \mathrm{e}^{-0.237 \mathrm{t}}$ & 15.3 & 0.81 & 0.081 \\
\hline Tithonia diversifolia & $Y=4.45+95.43 \mathrm{e}^{-0.266 t}$ & 3.92 & 0.99 & $<0.001$ \\
\hline Gliricidia sepium & $Y=24.83+74.9 \mathrm{e}^{-0.230 \mathrm{t}}$ & 11.8 & 0.91 & 0.026 \\
\hline \multicolumn{5}{|l|}{ Magnesium } \\
\hline Acacia auriculiformis & $Y=38.0+58.0 \mathrm{e}^{-0.097 \mathrm{t}}$ & 23.2 & 0.61 & 0.240 \\
\hline Senna spectabilis & $Y=5.78+93.44 \mathrm{e}^{-0.091 \mathrm{t}}$ & 5.34 & 0.99 & 0.001 \\
\hline Leucaena leucocephala & $Y=30.99+68.91 \mathrm{e}^{-0.135 \mathrm{t}}$ & 6.77 & 0.96 & 0.007 \\
\hline Tithonia diversifolia & $Y=2.43+97.33 \mathrm{e}^{-0.236 t}$ & 4.37 & 0.99 & $<0.001$ \\
\hline Gliricidia sepium & $Y=5.83+93.24 \mathrm{e}^{-0.129 \mathrm{t}}$ & 6.36 & 0.98 & 0.002 \\
\hline
\end{tabular}

nutrient cycling (Nziguheba et al. 2000) and soil fertility especially in places where mineral fertilizer applications are limited.

The applicability of using rates constants obtained from the single exponential model in describing best fitted decomposition and nutrient release patterns of plant materials have been contested (Wieder and Lang 1982; Ezcurra and Becerra 1987). However, the high $R^{2}$ values obtained from this study makes the single exponential model seem applicable. Statistical comparison of the decomposition constant of the species confirmed the fastest decomposition and nutrient release in $T$. diversifolia. This rapid decomposition and nutrient release rates of $T$. diversifolia leaf biomass is in agreement with the findings of 
Table 6 Pearson's correlation coefficient $(r)$ of the linear relationship between nutrient release rate and initial chemical characteristics of leaf materials

\begin{tabular}{llllll}
\hline Nutrient & \multicolumn{5}{l}{ Nutrient release rate } \\
\cline { 2 - 6 } & $k_{\mathrm{N}}$ & $k_{\mathrm{P}}$ & $k_{\mathrm{K}}$ & $k_{\mathrm{Ca}}$ & $k_{\mathrm{Mg}}$ \\
\hline $\mathrm{C}$ & -0.74 & -0.79 & -0.85 & -0.26 & -0.69 \\
$\mathrm{~N}$ & 0.78 & 0.80 & 0.79 & 0.41 & 0.68 \\
$\mathrm{P}$ & $0.93^{*}$ & $0.93^{*}$ & $0.94^{*}$ & 0.57 & 0.83 \\
$\mathrm{~K}$ & 0.75 & 0.66 & 0.53 & $0.89^{*}$ & 0.60 \\
$\mathrm{Ca}$ & 0.09 & 0.19 & 0.19 & 0.33 & 0.40 \\
$\mathrm{Mg}$ & $0.96^{* *}$ & $0.96^{* *}$ & $0.91^{*}$ & 0.81 & $0.92^{*}$ \\
$\mathrm{C}: \mathrm{N}$ & -0.75 & -0.75 & -0.74 & -0.40 & -0.62 \\
$\mathrm{C}: \mathrm{P}$ & -0.83 & -0.81 & -0.79 & -0.50 & -0.66
\end{tabular}

$*$ and $* *$ means significant at $5 \%$ and $1 \%$ probability levels, respectively

Gachengo et al. (1999) who reported a half-life of about 1 week for the disappearance of $T$. diversifolia dry matter in the rainy season in western Kenya. From the results, it was evident that substrate quality influences decomposition and nutrient release patterns of plant materials. The control of substrate quality in decomposition is highly documented and has been shown to be more influential than climatic factors in the tropics (Meentemeyer 1978; Palm and Sanchez 1990). In this study, neither N concentration nor $\mathrm{C} / \mathrm{N}$ ratio was useful in predicting decomposition and nutrient release rates. The assertion by Melillo and Aber (1983) that initial N concentration and C: N ratio influences the degradability of organic residues added to the soil was not confirmed by the results of this experiment. Results may be related to different decomposer communities which may have developed on plant materials based on their intrinsic qualities (Cobo et al. 2002). Among the plant chemical characteristics studied, only $\mathrm{P}$ and $\mathrm{Mg}$ concentrations served as useful indicators of degradability of plant materials based on significant results (Tables 6 and 9). The nutrient release patterns followed by the species studied demonstrate the importance of substrate quality in nutrient dynamics. Potassium happened to be the fastest release cation. The order of release of the cations $(\mathrm{Ca}<\mathrm{Mg}<\mathrm{K})$ are similarly reported by Palm and Sanchez (1990). The fastest release rate of potassium is in support of the hypothesis that leaching is the primary process influencing $\mathrm{K}$ losses (Swift et al. 1981). Net $\mathrm{N}$ immobilization occurred in all leguminous species (A. auriculiformis, S. spectabilis, L. leucocephala and G. sepium) which agrees with results from temperate regions (Berg and Staaf 1981; Melillo and Aber 1984). The lack of net $\mathrm{N}$ immobilization in nonleguminous species such as $T$. diversifolia is also reported (Swift et al. 1981; Anderson et al. 1983) in the tropics which is consistent with the observation made here. Phosphorus immobilization occurred only in L. leucocephala. Phosphorus immobilization during decomposition is reported at both tropical and temperate regions (Anderson et al. 1983; Melillo and Aber 1984; Palm and Sanchez 1990). This observation is said to occur when $\mathrm{P}$ is limiting to microbial activities (Melillo and Aber 1984; Schlesinger and Hasey 1981). It was evident from the study that $\mathrm{N}$ dynamics influenced $\mathrm{P}$ dynamics. All plant materials generally had a moderate to high $\mathrm{P}$ concentration in their tissues before decomposition but showed an increased $\mathrm{P}$ concentration at week 4 (Fig. 4) resulting in N/P ratios near ten, the ideal ratio for decomposer organisms (Vogt et al. 1986). N/P ratios generally increased to 23,30 and 19 at week 8 in A. auriculiformis, S. spectabilis, L. leucocephala and G. sepium respectively but dropped drastically thereafter. Lack of available $\mathrm{N}$ (toward the end of the experiment) should be more influential in this circumstance than phosphorus limitation (Palm and Sanchez 1990). This is evident in the independent $P$ mineralization at week 12. Further explanation is supported by the trend followed by $T$. diversifolia which maintained a N/P ratio near ten throughout the course of the study suggestion that $\mathrm{N}$ was controlling $P$ dynamics.

From the results obtained, there are clear indications that biomass quality affects the decomposition and nutrient release patterns of the selected plant leaf biomass. Based on the above results, the fresh leaves of $T$. diversifolia, S. spectabilis and G. sepium were rated as high quality litter and may be applied as green manure to short duration crops such as vegetables as well as most annual crops, due to their high $\mathrm{N}(>2.5 \%)$ and $\mathrm{P}(>0.25 \%)$ concentrations (Palm et al. 2001). Meanwhile, the accelerated decomposition and nutrient release of $T$. diversifolia may limit its potential for long term build-up of soil fertility. L. leucocephala leaves were rated as intermediate high quality litter due to the relatively low $\mathrm{P}$ concentration $(<0.25 \%)$ which might lead to 
Table 7 Nutrient release rates of different leaf materials as influenced by species type under field conditions
* Zero because leaf materials remaining could not be quantified. Leaf material was inseparable from soil mineral particles

a Nutrient release rates are in percentages

\begin{tabular}{|c|c|c|c|c|c|}
\hline \multirow[t]{2}{*}{ Nutrient release rate ${ }^{a} /$ species } & \multicolumn{5}{|c|}{ Sampling period (days) } \\
\hline & 7 & 14 & 28 & 56 & 84 \\
\hline \multicolumn{6}{|l|}{$N$ release rate $\left(k_{N}\right.$ day $\left.^{-1}\right)$} \\
\hline A. auriculiformis & 0.035 & 0.028 & 0.034 & 0.013 & 0.016 \\
\hline S. spectabilis & 0.071 & 0.056 & 0.055 & 0.026 & 0.025 \\
\hline L. leucocephala & 0.067 & 0.067 & 0.070 & 0.019 & 0.014 \\
\hline T. diversifolia & 0.309 & 0.184 & 0.132 & 0.072 & $0^{*}$ \\
\hline G. sepium & 0.170 & 0.153 & 0.082 & 0.035 & 0.029 \\
\hline $\mathrm{LSD}_{0.05}$ & 0.008 & 0.006 & 0.003 & 0.005 & 0.003 \\
\hline \multicolumn{6}{|l|}{$P$ release rate $\left(k_{P}\right.$ day $\left.^{-1}\right)$} \\
\hline A. auriculiformis & 0.039 & 0.040 & 0.025 & 0.021 & 0.020 \\
\hline S. spectabilis & 0.069 & 0.063 & 0.047 & 0.044 & 0.033 \\
\hline L. leucocephala & 0.065 & 0.061 & 0.053 & 0.027 & 0.015 \\
\hline T. diversifolia & 0.3 & 0.180 & 0.129 & 0.072 & $0^{*}$ \\
\hline G. sepium & 0.142 & 0.110 & 0.060 & 0.044 & 0.038 \\
\hline $\mathrm{LSD}_{0.05}$ & 0.019 & 0.019 & 0.010 & 0.002 & 0.002 \\
\hline \multicolumn{6}{|l|}{$K$ release rate $\left(k_{K}\right.$ day $\left.^{-1}\right)$} \\
\hline A. auriculiformis & 0.093 & 0.070 & 0.050 & 0.051 & 0.039 \\
\hline S. spectabilis & 0.086 & 0.097 & 0.091 & 0.071 & 0.054 \\
\hline L. leucocephala & 0.101 & 0.067 & 0.111 & 0.063 & 0.034 \\
\hline T. diversifolia & 0.265 & 0.158 & 0.173 & 0.093 & $0^{*}$ \\
\hline G. sepium & 0.141 & 0.118 & 0.173 & 0.075 & 0.051 \\
\hline $\mathrm{LSD}_{0.05}$ & 0.004 & 0.011 & 0.079 & 0.005 & 0.003 \\
\hline \multicolumn{6}{|l|}{ Ca release rate $\left(k_{\mathrm{Ca}} \mathrm{day}^{-1}\right)$} \\
\hline A. auriculiformis & 0.072 & 0.045 & 0.031 & 0.014 & 0.014 \\
\hline S. spectabilis & 0.071 & 0.059 & 0.004 & 0.025 & 0.021 \\
\hline L. leucocephala & 0.094 & 0.071 & 0.057 & 0.017 & 0.007 \\
\hline T. diversifolia & 0.247 & 0.154 & 0.107 & 0.053 & $0^{*}$ \\
\hline G. sepium & 0.143 & 0.072 & 0.072 & 0.018 & 0.02 \\
\hline $\mathrm{LSD}_{0.05}$ & 0.003 & 0.002 & 0.006 & 0.002 & 0.002 \\
\hline \multicolumn{6}{|l|}{ Mg release rate $\left(k_{\mathrm{Mg}} \mathrm{day}^{-1}\right)$} \\
\hline A. auriculiformis & 0.098 & 0.024 & 0.038 & 0.009 & 0.021 \\
\hline S. spectabilis & 0.097 & 0.068 & 0.089 & 0.044 & 0.033 \\
\hline L. leucocephala & 0.082 & 0.056 & 0.051 & 0.018 & 0.014 \\
\hline T. diversifolia & 0.241 & 0.148 & 0.146 & 0.076 & $0^{*}$ \\
\hline G. sepium & 0.136 & 0.088 & 0.123 & 0.047 & 0.033 \\
\hline $\mathrm{LSD}_{0.05}$ & 0.017 & 0.004 & 0.004 & 0.003 & 0.002 \\
\hline
\end{tabular}

immobilization of $\mathrm{P}$ or reduce the rate of mineralization despite the high levels of $\mathrm{N}$ in the leaves. Therefore, such materials may be composted to start the breakdown before application to crops (Palm et al. 2001). On the other hand, the fresh leaves of A. auriculiformis were rated as low quality litter due to the low levels of $\mathrm{N}(<2.5 \%)$ and $\mathrm{P}(<0.25 \%)$. The leaves may be unsuitable for use as a fertilizer technology. Meanwhile, A. auriculiformis fresh leaves may be used as surface mulch to protect soil against evaporative losses or to control surface water flow. Alternatively, the fresh leaves of A. auriculiformis may be mixed with very high grade organic matter or $\mathrm{N}$ and $\mathrm{P}$ fertilizers to compensate for the low N, P or both N and P levels (Palm et al. 2001). Furthermore, organic residues such as L. leucocephala 
Table 8 N, P, K concentration of green leaves of T. diversifolia as compared to other shrubs and trees (Jama et al. 2000)

\begin{tabular}{|c|c|c|c|c|c|c|}
\hline \multirow[t]{2}{*}{ Species } & \multicolumn{2}{|c|}{ Nitrogen $(\%)$} & \multicolumn{2}{|c|}{ Phosphorus (\%) } & \multicolumn{2}{|c|}{ Potassium $(\%)$} \\
\hline & Mean & Range & Mean & Range & Mean & Range \\
\hline Tithonia diversifolia & 3.5 & $3.1-4.0$ & 0.37 & $0.24-0.56$ & 4.1 & $2.7-4.8$ \\
\hline Calliandra calothyrsus & 3.4 & $1.1-4.5$ & 0.15 & $0.04-0.23$ & 1.1 & $0.6-1.9$ \\
\hline Crotalaria grahamiana & 3.2 & $3.0-3.6$ & 0.13 & $0.13-0.14$ & 1.3 & $0.9-1.6$ \\
\hline Lantana camara & 2.8 & $2.3-4.0$ & 0.25 & $0.18-0.30$ & 2.1 & $1.8-2.4$ \\
\hline Leucaena leucocephala & 3.8 & $2.8-6.1$ & 0.2 & $0.12-0.33$ & 1.9 & $1.3-3.4$ \\
\hline Sesbania sesban & 3.7 & $1.4-4.8$ & 0.23 & $0.11-0.43$ & 1.7 & $1.1-2.5$ \\
\hline Tephrosia vogelii & 3.0 & $2.2-3.6$ & 0.19 & $0.11-0.27$ & 1.0 & $0.5-1.3$ \\
\hline
\end{tabular}

Table 9 Relationship between percent rate of decomposition $\left(k_{\mathrm{D}}\right.$ day $\left.^{-1}\right)$ and chemical composition of leaf materials of the various species used in the experiment

\begin{tabular}{lllll}
\hline Element & Equation & $R^{2}$ & SE* $^{*}$ & $P$ value \\
\hline $\mathrm{N}$ & $k_{\mathrm{D}}=0.016(\mathrm{~N})-0.34$ & 0.68 & 0.06 & 0.088 \\
$\mathrm{P}$ & $k_{\mathrm{D}}=0.081(\mathrm{P})-0.1$ & 0.88 & 0.04 & 0.019 \\
$\mathrm{~K}$ & $k_{\mathrm{D}}=0.1007(\mathrm{~K})-0.48$ & 0.47 & 0.08 & 0.205 \\
$\mathrm{Ca}$ & $k_{\mathrm{D}}=0.004(\mathrm{Ca})+0.07$ & 0.03 & 0.10 & 0.793 \\
$\mathrm{Mg}$ & $k_{\mathrm{D}}=0.041(\mathrm{Mg})-0.14$ & 0.95 & 0.02 & 0.005 \\
$\mathrm{C}$ & $k_{\mathrm{D}}=-0.008(\mathrm{C})+3.79$ & 0.64 & 0.06 & 0.105 \\
$\mathrm{C}: \mathrm{N}$ & $k_{\mathrm{D}}=-0.021(\mathrm{C}: \mathrm{N})-0.48$ & 0.61 & 0.06 & 0.121 \\
$\mathrm{C}: \mathrm{P}$ & $k_{\mathrm{D}}=-0.001(\mathrm{C}: \mathrm{P})-0.29$ & 0.68 & 0.06 & 0.086 \\
\hline
\end{tabular}

$R^{2}=$ coefficient of determination, $*=$ standard error, $\$=$ significance of fit

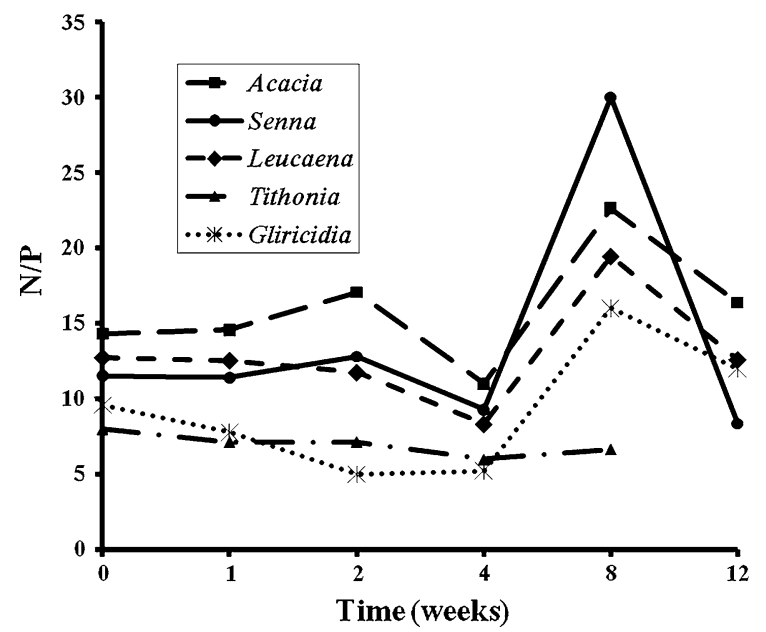

Fig. 4 Nitrogen-to-phosphorus ratios with time in the decomposing leaves of Tithonia diversifolia, Acacia auriculiformis, Senna spectabilis, Leucaena leucocephala and Gliricidia sepium and A. auriculiformis, which decompose and release nutrients slowly, can be considered for long-term build up of soil fertility.

Acknowledgment The authors wish to express their sincere gratitude to the Canadian International Development Agency (CIDA) for providing financial assistance to the corresponding author to carry-out this research as part of his postgraduate studies at the Kwame Nkrumah University of Science and Technology, Kumasi, Ghana under a CIDA-sponsored livelihood enhancement project (APERL) in Ghana, West Africa.

\section{References}

Anderson JM, Proctor J, Vallack HW (1983) Ecological studies in four contracting rain forests in Gunung Mulu national park, Sarawak, III. Decomposition processes and nutrient losses from leaf litter. J Ecol 71:503-527

Berg B, Staaf H (1981) Leaching, accumulation and release of nitrogen in decomposing forest litter. In: Clark FE, Rosswall T (eds) Terrestrial nitrogen cycles, pp. 163-178. Ecol. Bull. Vol. 33. Stockholm, Sweden

Cobo JG, Barrios E, Kass DCL, Thomas RJ (2002) Decomposition and nutrient release by green manures in a tropical hillside agroecosystem. Plant Soil 240:331-342

Ezcurra E, Becerra J (1987) Experimental decomposition of litter from the Tamaulipan cloud forest: a comparison of four simple models. Biotropica 19:290-296

Gachengo CN, Palm CA, Jama B, Othieno C (1999) Tithonia and Senna green manures and inorganic fertilizers as phosphorus sources for maize in western Kenya. Agroforest Syst 44:21-36

Garrity DP, Mercado AR (1994) Nitrogen fixation capacity in the component species of contour hedgerows: how important? Agroforest Syst 27:241-258

George TS, Gregory PJ, Robinson JS, Buresh RJ, Jama BA (2001) Tithonia diversifolia: variations in leaf nutrient concentration and implications for biomass transfer. Agroforest Syst 52:199-205

Getahun A, Wilson GF, Kang BT (1982) The role of trees in farming systems of the humid tropics. In LH Macdonald 
(ed.) Agroforestry in the African humid tropics. Proceedings of a workshop held at Ibadan, Nigeria. 27th April-1st May 1981

ICRAF (1997) Using the wild sunflower, T. diversifolia, in Kenya. International Centre for Research in Agroforestry, Nairobi, Kenya, p 5

Ikerra S, Semu E, Mrema J (2006) Combining T. diversifolia and minjingu phosphate rock for improvement of $\mathrm{P}$ availability and maize grain yields on a chromic acrisol in Morogoro, Tanzania. Nutr Cycl Agroecosys 76:249-260

Jama BA, Palm CA, Buresh RJ, Niang AI, Gachengo C, Nziguheba G, Amadalo B (2000) Tithonia diversifolia as a green manure for soil fertility improvement in western Kenya: a review. Agroforest Syst 49:201-221

Koenig RT, Cochran VL (1994) Decomposition and nitrogen mineralization from legume and non-legume crop residues in a subarctic agricultural soil. Biol Fertil Soils 17:269275

Kwabiah AB, Stoskopf NC, Voroney RP, Palm CA (2001) Nitrogen and phosphorus release from decomposing leaves under sub-humid tropical conditions. Biotropica 33:229-240

Meentemeyer V (1978) Macroclimate and lignin control of litter decomposition rates. Ecology 59:465-472

Melillo JM, Aber JD (1983) Nutrient immobilization in decaying litter: an example of carbon-nutrient interactions. In: JH Cooley and FB Golley (eds.) Trends in ecological research for the 1980s. Proceedings of a NATOARW and INTERCOL workshop residues on the future and use of ecology after the decade of the environment, Louvain-la-Neuve, Belgium. 7-9 April 1983. NATO, Plenum Press, New York

Melillo JM, Aber JD (1984) Nutrient immobilization in decaying litter: an example of carbon-nutrient interactions. In: Cooley JH, Golley Fb (eds) Trends in ecological research for the 1980s. Plenum Publishing Corporation, New York, pp 193-215

Motsara MR, Roy RN (2008) Guide to Laboratory establishment for plant nutrient analysis. FAO Fertilizer and Plant Nutrition Bulletin. Food and Agriculture Organization, Rome

Nair PKR (1984) Soil productivity aspects of agroforestry, vol 1. ICRAF Science and Practice of Agroforestry, Nairobi, p 85

Niang A, Amadalo B, Gathumbi S, Obonyo CO (1996) Maize yield response to green manure application from selected shrubs and tree species in western Kenya: a preliminary assessment. In Mugah JO (ed.) Proceedings of the first Kenya agroforestry conference on people and institutional participation in agroforestry for sustainable development. Kenya Forestry Research Institute (KEFRI), Muguga, Kenya; pp 350-358

Nye PH, Stephens D (1962) Soil fertility. In: Wills JB (ed) Agriculture and land use in Ghana. Oxford University Press, London, pp 127-143

Nziguheba G, Merckx R, Palm CA, Rao MR (2000) Organic residues affect phosphorus availability and maize yields in a Nitisol of western Kenya. Biol Fertil Soils 32:328-339
Palm CA, Sanchez PA (1990) Decomposition and nutrient release patterns of the leaves of three tropical legumes. Biotropica 22(4):330-338

Palm CA, Myers RJK, Nandwa SM (1997) Combined use of organic and inorganic nutrient sources for soil fertility maintenance and replenishment. In: Buresh RJ, Sanchez PA, Calhoun F (eds) Replenishing soil fertility in Africa: SSSA special publication number 51. ASA and SSSA, Madison, USA, pp 193-217

Palm CA, Gachengo CN, Delve RJ, Cadisch G, Giller K (2001) Organic inputs for soil fertility management in tropical agroecosystems: application of an organic resource database. Agricult Ecosyst Environ 83:27-42

Sanchez PA, Salinas JE (1981) Low input technology for managing oxisols and ultisols in tropical America. Adv Agrom 34:279-406

Schlesinger WH, Hasey MH (1981) Decomposition of chaparral shrub foliage: losses of organic and inorganic constituents from deciduous and evergreen leaves. Ecology 62:762-774

Schroth G (2003) Decomposition and nutrient supply from biomass. In: Schroth G, Sinclair FL (eds) Trees, crops and soil fertility concepts and research methods. CABI Publishing, UK, p 131

Sharrock RA, Sinclair FL, Gliddon C, Rao IM, Barrios E, Mustonen PJ, Smithson P, Jones DL, Godbold DL (2004) A global assessment using PCR techniques of mycorrhizal fungal populations colonizing Tithonia diversifolia. Mycorrhiza 14:103-109

Swift MJ, Heal OW, Anderson JM (1979) Decomposition in terrestrial ecosystems. Studies in ecology, vol 5. University of California Press, Berkeley, California

Swift MJ, Russel-Smith A, Perfect TJ (1981) Decomposition and mineral-nutrient dynamics of plant litter in a regenerating bush-fallow in sub-humid tropical Africa. J Ecol 69:981-995

Troeh FR, Thompson LM (2005) Soils and soil fertility, 6th edn. Blackwell Publishing Professional, USA, p 489

Vanlauwe B, Aihou K, Aman S, Iwuafor ENO, Tossah BK, Diels J, Sanginga N, Lyasse O, Merckx R, Deckers J (2001) Maize yield as affected by organic inputs and urea in the West African moist savannah. Agron J 93:11911199

Vitousek PM (1984) Litterfall, nutrient cycling, and nutrient limitation in tropical forests. Ecology 65:285-298

Vogt KA, Grier CC, Vogt DJ (1986) Production, turnover, and nutrient dynamics of above- and belowground detritus of world forests. Adv Ecol Res 15:303-377

VSN International Ltd. (2008) GENSTAT for Windows. Eleventh edition. VSN International, 5. The Waterhouse, Waterhouse Street, Hemel Hempstead, Hertfordshire HP1 1ES, UK

Wieder R, Lang G (1982) A critique of the analytical methods used in examining decomposition in litterbags. Ecology 63:1636-1642

Wu J, He ZL, Wei WX, O’Donnell AG, Syers JK (2000) Quantifying microbial biomass phosphorus in acid soils. Biol Fertil Soils 32:500-507 